\title{
Pengoptimuman Portofolio dengan Kendala Karakteristik Perusahaan Emiten
}

\author{
Ezra Putranda Setiawan ${ }^{1 *}$, Dedi Rosadi $^{1}$
}

\begin{abstract}
Asset diversification is often implemented by the investor to reduce the investment risk. Generally, diversification is carried out as specified by the result of a mathematical calculation based on each asset's historical return data, for example in the mean-variance model. In this study, we modify the mean-variance model by adding issuer company-related bound, i.e. the field of work, the owner of the company, or combination of both. The solution of this portfolio optimization problem could be obtained by the genetic algorithm. A case study by making portfolio that consist of several stocks in the Indonesia Stock Exchange are provided.
\end{abstract}

Keywords: Optimal portfolio, mean-variance model, Markowitz, genetic algorithm.

\section{Pendahuluan}

Kegiatan investasi di pasar modal tentu bertujuan untuk memperoleh keuntungan. Di sisi lain, kegiatan investasi juga mengandung risiko berupa kerugian, yakni bila harga aset yang dimiliki mengalami penurunan. Secara teoritis, risiko investasi dapat dibedakan menjadi dua kelompok, yakni risiko sistematis (systematic risk) dan risiko tak sistematis (non-systematic risk) (Samsul [1]). Risiko sistematik, disebut juga risiko pasar (market risk) atau risiko umum (general risk), ditimbulkan oleh kejadiankejadian di luar perusahaan, misalnya inflasi, resesi, perubahan tingkat suku bunga, dan sebagainya. Risiko tidak sistematis, disebut juga risiko spesifik (specific risk) atau risiko perusahaan (company risk), disebabkan oleh kejadian-kejadian di dalam perusahaan penerbit saham, sehingga bersifat unik atau spesifik untuk masing-masing perusahaan penerbit saham, dapat timbul karena adanya ketidakpastian usaha, penurunan hasil penjualan, dan lain sebagainya. Berbeda dengan risiko pasar, risiko spesifik dapat dikendalikan dengan melakukan diversifikasi atau peragaman aset, sehingga kerugian yang terjadi pada saham suatu perusahaan dapat dinetralkan pengaruhnya oleh keuntungan dari saham perusahaan lain (Goetzmann dan Kumar [2]). Besarnya pengaruh diversifikasi terhadap penurunan risiko investasi dapat dilihat secara jelas pada (Elton et al. [3]).

Diversifikasi aset dalam portofolio menimbulkan tantangan baru, yakni penentuan saham-saham yang turut menyusun portofolio dan banyaknya masing-masing saham dalam sebuah portofolio.

${ }^{1}$ Fakultas Matematika dan Ilmu Pengetahuan Alam, Program Studi Matematika, Universitas Gadjah Mada, Sekip Utara, Bulaksumur, Yogyakarta 55281, Indonesia.

Email: e2r4.ps@gmail.com, dedirosadi@gadjahmada.edu.

* Penulis korespondensi
Secara sederhana, Elton et al. [3] menunjukkan adanya kemungkinan diversifikasi secara acak (random) tanpa memperhatikan faktor apapun. Metode lain yang jauh lebih populer adalah model mean-variance, yang diperkenalkan oleh Markowitz [4]. Dalam model ini, Markowitz memperkenalkan penggunaan ragam (variance) saham sebagai ukuran risiko portofolio, sehingga tujuan investasi yang optimum adalah meminimumkan nilai ragam yang terbentuk. Model mean-variance telah digunakan secara luas, bahkan mengalami berbagai modifikasi atau penyempurnaan. Sebagai contoh, dalam (Supandi et al. [5]) dibahas model mean-variance yang dimodifikasi dengan penambahan penduga robust dan penggunaan metode pengoptimuman robust. Dalam (Soleimani et al. [6]), dibahas model mean variance dengan modifikasi lain berupa pembatasan lot transaksi, kardinalitas, dan kapitalisasi sektor. Lebih lanjut, dalam (Lhwin and $\mathrm{Qu}$ [7]) dibahas penggunaan metode-metode hybrid untuk penyelesaian masalah pengoptimuman portofolio Markowitz yang telah dimodifikasi dengan penambahan batasan kardinalitas maupun batasan bobot masing-masing saham.

Mengacu pada model Markowitz, ragam portofolio merupakan jumlahan dari dua komponen, yakni ragam masing-masing saham dan kovariansi antara tiap pasang aset dalam portofolio (Elton et al. [3]). Oleh karena itu, upaya meminimumkan ragam melibatkan dua upaya, yakni memilih sahamsaham dengan risiko rendah dan memilih sahamsaham yang nilai kovariansinya kecil. Dalam hal ini, kovariansi mengukur hubungan antara pergerakan return dua aset, dapat bernilai negatif, nol, maupun positif. Aset-aset yang pergerakan harga sahamnya tidak berhubungan memiliki kovariansi dekat dengan nol, sedangkan aset-aset yang pergerakan harga sahamnya berlawanan arah memiliki kovariansi negatif. Kedua tipe aset inilah yang dapat memperkecil risiko suatu portofolio. 
Di sisi lain, saham-saham perusahaan pada bidang usaha yang sama cenderung merespon perubahan situasi dengan cara yang hampir sama. Sebagai contoh, penurunan harga minyak dunia akan menyebabkan penurunan harga saham-saham perusahaan di bidang perminyakan (Adam et al. [8]). Sebaliknya, respon harga saham terhadap perubahan faktor-faktor makroekonomi juga dipengaruhi oleh bidang usaha perusahaannya. Mutumanikam [9] menunjukkan bahwa indeks saham perusahaan di bidang properti dipengaruhi oleh perubahan suku bunga Bank Indonesia (SBI), namun tidak dipengaruhi oleh inflasi. Hartanto [10] menyebutkan bahwa indeks saham sektor properti juga dipengaruhi oleh kurs mata uang asing terhadap rupiah. Penelitian lain, Hartanto [11] menunjukkan bahwa krisis moneter dapat memberikan pengaruh berbeda terhadap saham-saham di bidang yang berlainan. Oleh karena itu, masuk akal bila diversifikasi juga dilakukan terhadap bidang usaha masing-masing saham penyusun portofolio, yakni dengan membatasi saham-saham dari bidang atau sektor yang sama. Rahmi [12] menunjukkan bahwa portofolio yang disusun oleh saham-saham dari tiga sektor usaha yang berlainan memiliki kinerja yang lebih baik dibandingkan portofolio pasar. Oleh karena itu, dapat diduga bahwa pembentukan portofolio yang didasarkan pada diversifikasi sektor-sektor usaha akan memberikan hasil yang lebih baik dibandingkan portofolio yang dibentuk tanpa melihat sektor-sektor usahanya.

Lebih lanjut, diversifikasi juga dapat dilakukan terhadap pemilik perusahaan, yakni dengan membedakan Badan Usaha Milik Negara (BUMN) dan perusahaan swasta. Isdiansyah [13] menyatakan adanya perbedaan kinerja saham-saham BUMN dan saham-saham perusahaan swasta di bidang perbankan. Proses diversifikasi juga dapat dilakukan untuk membedakan perusahaan yang seluruh modalnya dimiliki di dalam negeri dan perusahaan yang sebagian besar modalnya dimiliki asing.

Berdasarkan hasil riset-riset empiris di atas, diperlukan adanya model pembentukan portofolio optimum yang pemilihan saham-sahamnya didasarkan pada kriteria terkait perusahaan emiten, baik berupa status kepemilikan, bidang atau sektor usaha, maupun berbagai kriteria fundamental lainnya. Model ini membantu investor atau manajer investasi dapat memastikan diversifikasi sektoral maupun diversifikasi berdasarkan kepemilikan perusahaan. Model pembentukan portofolio investasi optimum dengan kriteria-kriteria terkait perusahaan emiten yang dikembangkan dalam penelitian ini.

\section{Metode Penelitian}

Misalkan tersedia $N$ kandidat saham yang akan digunakan untuk membentuk portofolio optimum.
Misalkan pula $p_{i t}$ menyatakan harga saham ke- $i, i=$ $1,2,3, \ldots, N$ pada waktu $t, t=0,1,2,3, \ldots, T$, dengan $T$ banyaknya periode observasi data. Menurut Elton et al. [3], besarnya tingkat pengembalian (return) aset ke-i pada waktu ke- $t$ dapat dihitung sebagai

$r_{i t}=\log \left(\frac{p_{i t}}{p_{i t-1}}\right)=\log \left(p_{i t}\right)-\log \left(p_{i t-1}\right)$.

Diperhatikan sebuah portofolio yang terdiri dari $M$ aset $(M \leq N)$ dengan bobot masing-masing aset berturut-turut $w_{1}, w_{2}, \ldots, w_{\mathrm{M}}$, yang memenuhi hubungan

$w_{1}+w_{2}+w_{3}+\cdots+w_{M}=1$

Ragam tingkat pengembalian portofolio tersebut dapat dinyatakan sebagai

$\sigma_{p}=\sum_{i=1}^{M} \sum_{j=1}^{M} w_{i} w_{j} \sigma_{i j}$

dengan $\sigma_{i j}$ menyatakan kovariansi aset ke- $i$ dengan aset ke-j.

\section{Model Pengoptimuman Portofolio Mean- Variance}

Bobot portofolio optimum model mean-variance diperoleh dengan menyelesaikan masalah pemrograman kuadratis yang meminimumkan ragam tingkat pengembalian portofolio, yakni

$\min \sigma_{p}=\sum_{i=1}^{M} \sum_{j=1}^{M} w_{i} w_{j} \sigma_{i j}$

dengan kendala

$\sum_{i=1}^{M} w_{i} \mu_{i}=\mu_{0}$

$\sum_{i=1}^{M} w_{i}=1 \quad$ dan

$w_{i} \geq 0, i=1,2, \ldots, M$.

Pada kendala pertama pemrograman kuadratis di atas, $\mu_{0}$ menyatakan tingkat pengembalian minimum yang diharapkan, sedangkan $\mu_{i}$ menyatakan rata-rata tingkat pengembalian aset ke- $i$. Kendala berikut menjamin bahwa total bobot tidak melebihi keseluruhan modal yang tersedia, sedangkan kendala terakhir menyatakan bahwa penjualan pendek (short sell) tidak diperbolehkan. Apabila hanya kendala kedua yang digunakan, akan diperoleh portofolio dengan ragam minimum global (global minimum variance portfolio), yakni portofolio dengan risiko terkecil. Bobot portofolio ragam minimum ini dapat diperoleh dengan metode pengali Lagrange (Elton et al. [3]).

\section{Penambahan Kendala Kriteria Perusahaan Emiten}

Diperhatikan bahwa kendala kriteria perusahaan emiten saham merupakan variabel bertipe kategori, misalnya status kepemilikan perusahaan (BUMN atau swasta) atau bidang usaha (pertambangan, perdagangan, manufaktur, real estate, perkebunan, dan sebagainya). Didefinisikan himpunan $A$ sebagai himpunan saham-saham yang memenuhi kriteria 
Tabel 1. Ilustrasi deskripsi perusahaan emiten 8 saham

\begin{tabular}{ccll}
\hline Saham & Perusahaan & Bidang Usaha & Status \\
\hline 1 & $\mathrm{M}$ & Perdagangan & BUMN \\
2 & $\mathrm{~N}$ & Perkebunan & Swasta \\
3 & $\mathrm{O}$ & Pertambangan & BUMN \\
4 & $\mathrm{P}$ & Perkebunan & BUMN \\
5 & $\mathrm{R}$ & Real estate & BUMN \\
6 & $\mathrm{~S}$ & Perkebunan & Swasta \\
7 & $\mathrm{U}$ & Perkebunan & Swasta \\
8 & $\mathrm{~V}$ & Perbankan & BUMN \\
\hline
\end{tabular}

tertentu (misal perusahaan BUMN). Selanjutnya untuk $N$ saham yang tersedia, dibentuk dua variabel biner $c_{j}$ dan $z_{\mathrm{j}}$, yakni

$$
c_{i}= \begin{cases}1 & \text { bila saham ke } i \in A \\ 0 & \text { bila saham ke } i \notin A\end{cases}
$$

dan

$z_{i}=\left\{\begin{array}{cc}1 & \text { bila saham ke i dimasukkan portofolio } \\ 0 & \text { bila saham ke i tidak dimasukkan portofolio }\end{array}\right.$

Mudah dipahami bahwa $z_{\mathrm{i}}=0$ ekuivalen dengan $w_{\mathrm{i}}$ $=0$. Selanjutnya, ke dalam pemrograman kuadratis (4) ditambahkan kendala

$\sum_{i=1}^{N} c_{i} z_{i} \leq L$

dengan $L$ menyatakan nilai maksimum banyaknya saham anggota himpunan $A$ (memenuhi kriteria tertentu) yang diharapkan terdapat dalam portofolio.

Berikut ilustrasi mengenai penerapan kendala kriteria emiten yang telah dideskripsikan di atas. Misalkan dimiliki data delapan buah saham yang diberi nomor $1,2,3, \ldots, 8$. Deskripsi masing-masing perusahaan emiten delapan saham tersebut disajikan pada Tabel 1.

Misal akan dibentuk portofolio dengan tepat dua saham dari sektor perkebunan, sehingga himpunan A pada contoh ini merupakan himpunan sahamsaham persahaan yang bergerak di sektor perkebunan dan nilai batas $L=2$. Berdasarkan Tabel 1, anggota himpunan A adalah saham-saham perusahaan N, P, S, dan U. Dengan demikian diperoleh $c_{2}=c_{4}=c_{6}=c_{7}=1$ dan $c_{1}=c_{3}=c_{5}=c_{8}=0$, dan kendala (7) menjadi

$z_{2}+z_{4}+z_{6}+z_{7}=2$

Mudah dipahami bahwa kendala (8) hanya akan dipenuhi bila terdapat tepat dua saham sektor perkebunan di dalam portofolio. Sebagai contoh, bila saham $\mathrm{N}$ dan $\mathrm{S}$ turut menyusun portofolio, berdasarkan (6) didapat $z_{2}=z_{7}=1$ dan $z_{4}=z_{6}=0$, sehingga (8) menjadi $1+0+0+1=2$. Bila saham $\mathrm{P}$ juga dimasukkan ke dalam portofolio, akan diperoleh $z_{2}=z_{4}=z_{7}=1$, sehingga jumlahan (8) tidak dipenuhi. Saham-saham di luar sektor perkebunan tidak akan berpengaruh terhadap kendala tersebut.
Ilustrasi selanjutnya, misal akan dibentuk portofolio dengan maksimal tiga saham dari perusahaan milik negara (BUMN). Dari Tabel 1, dapat dibentuk himpunan A dengan anggota saham-saham perusahaan M, O, P, R, dan V, sehingga diperoleh kendala

$z_{1}+z_{3}+z_{4}+z_{5}+z_{8} \leq 3$

Seperti pada kendala (8), kendala (9) ini hanya dipengaruhi oleh saham-saham BUMN; tidak dapat dibentuk portofolio dengan lebih dari tigas saham perusahaan BUMN.

Model di atas dapat pula dikembangkan untuk mengakomodasi lebih dari satu kendala kriteria perusahaan emiten. Untuk itu dibentuk beberapa himpunan yakni $A_{1}, A_{2}, \ldots, A_{\eta}$ yang berturut-turut memuat saham-saham perusahaan emiten yang memenuhi kriteria pertama, kriteria kedua, hingga kriteria ke- $\eta$. Dengan demikian, persamaan (5) harus diperluas menjadi

$c_{i j}= \begin{cases}1 & \text { bila saham ke } i \in A_{j} \\ 0 & \text { bila saham ke } i \notin A_{j}\end{cases}$

dan kendala (7) diubah menjadi

$\sum_{i=1}^{N} c_{i j} z_{i} \leq L_{j}$, untuk $j=1,2, \ldots, \eta$.

Terlihat jelas bahwa untuk $\eta$ buah kriteria terkait dengan perusahaan emiten, perlu ditambahkan $\eta$ buah kendala, yakni satu kendala untuk masingmasing kriteria. Dalam hal ini, kriteria-kriteria tersebut tidak harus bersifat saling asing.

\section{Penyelesaian Masalah}

Penambahan kendala berupa kriteria perusahaan emiten ke dalam model pengoptimuman portofolio dapat dipandang sebagai perluasan dari pembatasan kardinalitas (cardinality constraint), yakni pembatasan jumlah total aset yang dapat dimasukkan ke dalam portofolio. Gagasan mengenai pembatasan kardinalitas telah muncul dalam beberapa literatur, misalnya Bienstock [14], Chang et al. [15], WoodsideOriakhi [16], Angelelli et al. [17], dan Mansini et al. [18]. Mengacu pada literatur-literatur tersebut, penyelesaian masalah pengoptimuman portofolio dengan pembatasan kardinalitas dapat dilakukan dengan sejumlah metode heuristik, misalnya algoritma genetika, pencarian Tabu (tabu search), pencarian lokal (local search) hibrid, dan simulated annealing.

Berdasarkan Chang et al. [15] dan WoodsideOriakhi [16], diketahui bahwa penyelesaian masalah pengoptimuman portofolio dengan metode algoritma genetika lebih unggul dibandingkan metode-metode penyelesaian heuristik lainnya. 
Algoritma genetika juga lebih unggul dibandingkan dengan pemrograman kuadratik (Lin dan Liu [19]), dalam hal penyederhanaan kompleksitas serta kemudahan dalam menambahkan batasan-batasan. Oleh karena itu, dalam penelitian ini, model pengoptimuman portofolio dengan penambahan kendala terkait kriteria perusahaan emiten akan diselesaikan dengan metode algoritma genetika.

Algoritma Genetika merupakan salah satu metode heuristik yang dikembangkan berdasarkan prinsip genetika dan proses seleksi alam, teori Evolusi Darwin (Zuhri [20]). Menurut (Haupt dan Haupt [21]), algoritma genetika dikembangkan oleh John Holland pada dekade 1960-an, dan dipopulerkan pada tahun 1980-an oleh David Goldberg. Penerapan algoritma genetika dalam penyelesaian masalah portofolio dikembangkan oleh Arnone et al. [22], dan digunakan secara luas dalam beberapa penelitian mengenai pengoptimuman portofolio dengan berbagai tambahan kendala, misalnya (Soleimani et al. [6], Chang et al. [15], Lin dan Liu [19], dan Chang et al. [23]).

\section{Implementasi dalam Algoritma Genetika Biner}

Dalam penelitian ini, algoritma genetika hanya digunakan untuk menentukan saham-saham yang diikutsertakan dalam portofolio optimum. Selanjutnya, bobot portofolio optimum diperoleh dengan menyelesaikan model mean variance dengan pemrograman kuadratis. Adapun langkah-langkah pemilihan saham dengan menggunakan algoritma genetika adalah sebagai berikut.

(1) Lakukan inisialisasi dengan membentuk populasi yang terdiri dari sejumlah kromosom. Masingmasing kromosom tersusun atas $N$ bit kode biner, yang merepresentasikan variabel $z_{1}, z_{2}, \ldots, z_{\mathrm{N}}$. Proses inisialisasi populasi dilakukan secara acak.

(2) Bentuk fungsi fitness untuk mengukur risiko dari portofolio optimum yang terbentuk dari aset-aset yang terpilih. Masukan fungsi fitness ini berupa kromosom yang terbentuk dari langkah (1) sebagai dasar pemilihan aset-aset yang akan dimasukkan ke dalam portofolio optimum. Selanjutnya, dihitung nilai variansi sebagai ukuran risiko portofolio tersebut.

fitness $=$-variansi minimum portofolio-penalti

Seperti ditunjukkan pada persamaan (12) di atas, nilai akhir fungsi fitness masing-masing kromosom adalah negatif dari variansi minimum portofolio yang dapat dibentuk. Tanda negatif digunakan karena tujuan pengoptimuman adalah meminimumkan variansi, sementara tujuan algoritma genetika adalah mencari kromosom dengan fitness tertinggi. Fungsi pinalti (penalty function) ditam- bahkan untuk memastikan bahwa seluruh kendala (terkait dengan kriteria perusahaan emiten) telah dipenuhi. Untuk masing-masing kendala, dapat dibentuk vektor kendala, dalam bentuk $\left(\begin{array}{llll}c_{1} & c_{2} & \cdots & c_{N}\end{array}\right)$ dengan masing-masing $c_{i}$ didefinisikan oleh persamaan (5) di muka. Misalkan pula batas maksimum jumlah saham terkait dengan kendala tersebut adalah $l$. Fungsi penalti akan memastikan bahwa portofolio yang terbentuk tidak melebihi batas maksimum tersebut. Untuk itu, berdasarkan nilai-nilai kromosom yang dimasukkan, fungsi penalti dapat didefinisikan sebagai berikut:

penalti $=\left\{\begin{array}{cc}0 & \text { bila } \sum_{i} c_{i} z_{i} \leq l \\ 100 & \text { bila } \sum_{i} c_{i} z_{i}>l\end{array}\right.$

Dari persamaan (13), terlihat bahwa kromosom yang tidak memenuhi kendala akan memiliki nilai fungsi penalti lebih besar dibandingkan kromosom yang memenuhi kendala pengoptimuman, sehingga berdasarkan persamaan (12), kromosom yang tidak memenuhi kendala akan memiliki nilai fitness yang lebih rendah.

(3) Lakukan evaluasi kebugaran masing-masing kromosom. Nilai fungsi fitness yang lebih tinggi merepresentasikan aset-aset pembentuk portofolio yang memenuhi seluruh persyaratan atau kendala, dengan risiko yang lebih kecil.

(4) Lakukan perubahan kromosom-kromosom menggunakan operator mutasi maupun persilangan (crossing over), berturut-turut dengan probabilitas sebesar $p_{\mathrm{m}}$ dan $p_{\mathrm{c}}$. Nilai probabilitas dapat ditentukan melalui percobaan maupun mengacu pada penelitian-penelitian sebelumnya, misal Elton et al. [3], Woodside-Oriakhi [16], Lin dan Liu [19], Haupt dan Haupt [21], dan Chang et al. [23]. Pemilihan kromosom yang disilangkan dilakukan dengan metode roulette wheel, yakni dengan memberikan prioritas pemilihan pada kromosom-kromosom dengan nilai fitness lebih tinggi.

(5) Lakukan penggantian (seleksi) terhadap kromosom-kromosom populasi yang memiliki nilai fitness relatif rendah dibandingkan dengan kromosom hasil langkah 4. Beberapa kromosom yang memiliki nilai fitness relatif lebih tinggi dibandingkan kromosomkromosom lainnya tetap disimpan sebagai kandidat solusi terbaik (prinsip elitisme).

(6)Langkah 4 dan 5 dilakukan terus menerus hingga diperoleh solusi yang stabil, yakni ketika nilai fungsi fitness tidak lagi mengalami perubahan selama beberapa generasi. Portofolio dengan nilai fitness tertinggi dinyatakan sebagai portofolio terbaik.

\section{Hasil dan Pembahasan}

Mengacu pada Goetzmann dan Kumar [2], LQ-45 merupakan salah satu indeks saham di Bursa Efek Indonesia yang beranggotakan 45 saham terpilih dengan kinerja unggul yang paling aktif diperda- 
Tabel 2. Profil perusahaan emiten saham-saham anggota indeks LQ-45 Januari-Juli 2017

\begin{tabular}{|c|c|c|c|c|c|c|}
\hline Nomor & Kode Saham & Sektor Industri & Status & Status Syariah & Mean return & Simpangan baku return \\
\hline 1 & AALI & Perkebunan & Swasta & $\mathrm{Ya}$ & 0,002260 & 0,000222 \\
\hline 2 & $\mathrm{ADHI}$ & Properti dan Real Estate & BUMN & $\mathrm{Ya}$ & $-0,004580$ & 0,000508 \\
\hline 3 & $\mathrm{ADRO}$ & Pertambangan & Swasta & $\mathrm{Ya}$ & $-0,001467$ & 0,000492 \\
\hline 4 & AKRA & Perdagangan dan Jasa & Swasta & $\mathrm{Ya}$ & $-0,000148$ & 0,000414 \\
\hline 5 & ANTM & Pertambangan & Swasta & $\mathrm{Ya}$ & $-0,003177$ & 0,000608 \\
\hline 6 & ASII & Otomotif (lain-lain) & Swasta & $\mathrm{Ya}$ & $-0,001152$ & 0,000208 \\
\hline 7 & ASRI & Properti dan Real Estate & Swasta & $\mathrm{Ya}$ & $-0,004584$ & 0,000340 \\
\hline 8 & $\mathrm{BBCA}$ & Bank & Swasta & Tidak & 0,00001 & 0,000131 \\
\hline 9 & BBNI & Bank & BUMN & Tidak & 0,000177 & 0,000193 \\
\hline 10 & BBRI & Bank & BUMN & Tidak & 0,001259 & 0,000191 \\
\hline 11 & BBTN & Bank & BUMN & Tidak & 0,000496 & 0,000337 \\
\hline 12 & BMRI & Bank & BUMN & Tidak & 0,000392 & 0,000194 \\
\hline 13 & BSDE & Properti dan Real Estate & Swasta & $\mathrm{Ya}$ & $-0,000299$ & 0,000314 \\
\hline 14 & BUMI & Pertambangan & Swasta & Tidak & 0,000013 & 0,003688 \\
\hline 15 & CPIN & Industri dasar dan kimia & Swasta & $\mathrm{Ya}$ & $-0,002112$ & 0,000496 \\
\hline 16 & ELSA & Pertambangan & Swasta & $\mathrm{Ya}$ & $-0,007688$ & 0,000526 \\
\hline 17 & EXCL & Infrastruktur dan Komunikasi & Swasta & $\mathrm{Ya}$ & $-0,000918$ & 0,000690 \\
\hline 18 & GGRM & Barang konsumsi & Swasta & Tidak & 0,000452 & 0,000310 \\
\hline 19 & HMSP & Barang konsumsi & Swasta & Tidak & $-0,000596$ & 0,000235 \\
\hline 20 & ICBP & Barang konsumsi & Swasta & $\mathrm{Ya}$ & $-0,000440$ & 0,000259 \\
\hline 21 & INCO & Pertambangan & Swasta & $\mathrm{Ya}$ & $-0,002698$ & 0,000748 \\
\hline 22 & INDF & Barang konsumsi & Swasta & $\mathrm{Ya}$ & $-0,000070$ & 0,000243 \\
\hline 23 & INTP & Industri dasar dan kimia & Swasta & $\mathrm{Ya}$ & 0,000959 & 0,000339 \\
\hline 24 & JSMR & Infrastruktur dan Komunikasi & BUMN & $\mathrm{Ya}$ & $-0,000887$ & 0,000277 \\
\hline 25 & $\mathrm{KLBF}$ & Barang konsumsi & Swasta & $\mathrm{Ya}$ & 0,000207 & 0,000284 \\
\hline 26 & LPKR & Properti dan Real Estate & Swasta & $\mathrm{Ya}$ & 0,000001 & 0,000335 \\
\hline 27 & LPPF & Perdagangan dan Jasa & Swasta & $\mathrm{Ya}$ & $-0,002948$ & 0,000580 \\
\hline 28 & LSIP & Perkebunan & Swasta & $\mathrm{Ya}$ & $-0,004031$ & 0,000336 \\
\hline 29 & MNCN & Perdagangan dan Jasa & Swasta & $\mathrm{Ya}$ & $-0,000868$ & 0,000522 \\
\hline 30 & MYRX & Properti dan Real Estate & Swasta & $\mathrm{Ya}$ & $-0,002560$ & 0,000718 \\
\hline 31 & PGAS & Infrastruktur dan Komunikasi & BUMN & $\mathrm{Ya}$ & $-0,003414$ & 0,000399 \\
\hline 32 & PPRO & Properti dan Real Estate & Swasta & $\mathrm{Ya}$ & $-0,002585$ & 0,000919 \\
\hline 33 & PTBA & Pertambangan & BUMN & $\mathrm{Ya}$ & $-0,002462$ & 0,000628 \\
\hline 34 & PTPP & Properti dan Real Estate & BUMN & $\mathrm{Ya}$ & $-0,004010$ & 0,000415 \\
\hline 35 & PWON & Properti dan Real Estate & Swasta & $\mathrm{Ya}$ & $-0,001601$ & 0,000547 \\
\hline 36 & SCMA & Perdagangan dan Jasa & Swasta & Tidak & $-0,002036$ & 0,000472 \\
\hline 37 & SMGR & Industri dasar dan kimia & BUMN & $\mathrm{Ya}$ & 0,000148 & 0,000253 \\
\hline 38 & SMRA & Properti dan Real Estate & Swasta & $\mathrm{Ya}$ & $-0,003764$ & 0,000544 \\
\hline 39 & SRIL & Industri lain-lain & Swasta & Tidak & $-0,003055$ & 0,001530 \\
\hline 40 & SSMS & Perkebunan & Swasta & $\mathrm{Ya}$ & $-0,001577$ & 0,000368 \\
\hline 41 & TLKM & Infrastruktur dan komunikasi & BUMN & $\mathrm{Ya}$ & 0,000917 & 0,000156 \\
\hline 42 & UNTR & Perdagangan dan Jasa & Swasta & $\mathrm{Ya}$ & 0,001198 & 0,000521 \\
\hline 43 & UNVR & Barang konsumsi & Swasta & $\mathrm{Ya}$ & 0,000382 & 0,000144 \\
\hline 44 & WIKA & Properti dan Real Estate & BUMN & $\mathrm{Ya}$ & $-0,005578$ & 0,000440 \\
\hline 45 & WSKT & Properti dan Real Estate & BUMN & $\mathrm{Ya}$ & $-0,002482$ & 0,000326 \\
\hline
\end{tabular}

Sumber: Publikasi indeks LQ45 Februari 2017, Indonesia stock exchange.

gangkan di Bursa Efek Indonesia. Saham-saham penyusun indeks ini selalu dievaluasi setiap enam bulan, dan diterbitkan menjelang bulan Februari dan Agustus. Oleh karena itu, saham-saham penyusun indeks LQ-45 ini dapat dianggap mewakili saham-saham dengan kinerja unggul di Bursa Efek Indonesia.

Dalam penelitian ini akan dibentuk portofolio berdasarkan saham-saham yang menyusun indeks LQ45 periode Agustus 2017. Sebagai acuan perhitungan digunakan data return saham harian pada periode September 2016 sampai dengan Agustus 2017, yakni sebanyak 220 data. Profil perusahaan emiten saham-saham LQ-45 dapat dilihat pada Tabel 2.

Dari data pada tabel 2 terlihat adanya tiga kriteria perusahaan emiten yang dapat digunakan, yakni sektor usaha (mengacu pada 10 macam sektor usaha di Bursa Efek Indonesia), status kepemilikan perusahaan (BUMN dan/atau Swasta), dan penggolongan jenis usaha syariah/non syariah. Di samping itu, dapat pula dilakukan klasifikasi berdasarkan berbagai kriteria fundamental, misalnya rasio-rasio akuntansi. Pendek kata, terdapat berbagai cara untuk membentuk kriteria saham-saham penyusun portofolio optimum. 


\section{Pengoptimuman Portofolio Mean-Variance Markowitz}

Pada tahap ini akan dihitung portofolio optimum menurut model mean-variance Markowitz [4] dengan memasukkan seluruh saham yang tersedia pada Tabel 2. Bobot portofolio yang terbentuk dari perhitungan ini ditunjukkan pada Gambar 1 .

Dari Gambar 1, terlihat bahwa portofolio optimum dari saham-saham LQ-45 menurut model klasik mean-variance Markowitz [4] tersusun oleh 21 macam saham, dengan bobot terkecil adalah 0,5\% (TLKM) dan bobot terbesar adalah BBCA (21,5\%). Ditinjau dari status kepemilikan saham, terdapat delapan saham perusahaan perseroan BUMN

dengan bobot sebesar 24,4\% (dari total 12 saham yang tersedia) dan 13 saham perusahaan swasta dengan bobot sebesar 75,6 \% (dari total 33 saham yang tersedia).
Lebih lanjut, saham-saham penyusun portofolio optimum tersebut dapat diklasifikasikan berdasarkan sektor bidang usahanya, seperti terlihat pada Tabel 3.

Pada Tabel 3, terlihat bahwa portofolio optimal didominasi oleh saham-saham dari dua sektor, yakni sektor perbankan dengan bobot sebesar 34,7\% dan sektor perkebunan dengan bobot sebesar 23,8\%.

\section{Penambahan Kendala terkait Perusahaan Emiten}

Pada bagian ini akan dibentuk beberapa portofolio menggunakan metode Markowitz dengan penambahan kendala terkait sektor lapangan usaha, status kepemilikan perusahaan emiten, dan kombinasi keduanya. Sebagai contoh, berdasarkan uraian di atas terlihat bahwa portofolio optimum pada saham-saham penyusun indeks LQ-45 didominasi oleh saham dari sektor perbankan (bobot
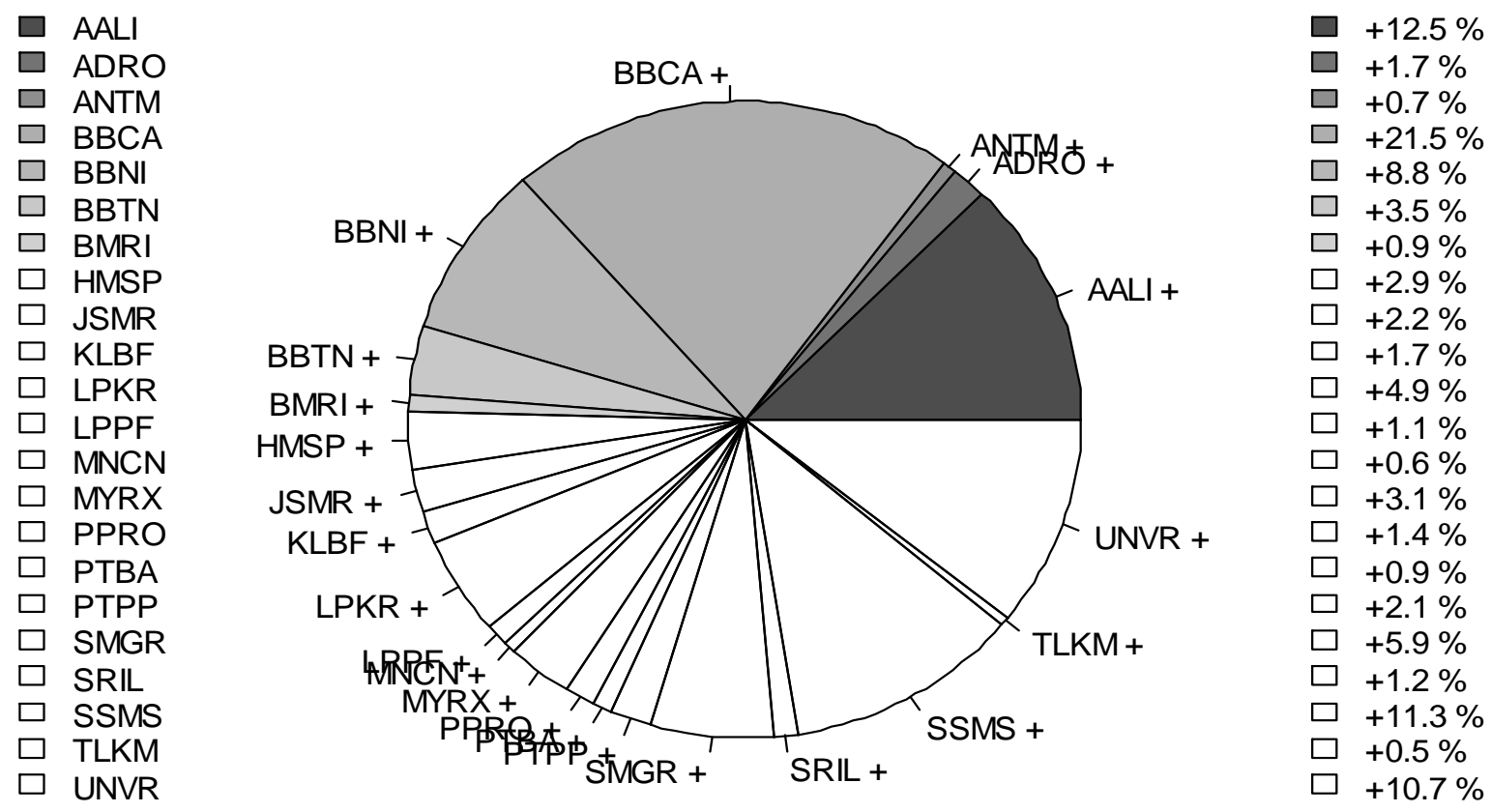

Gambar 1. Bobot portofolio mean variance berdasarkan saham-saham pada Tabel 2

Tabel 3. Komposisi sektor-sektor saham dalam portofolio optimum

\begin{tabular}{|c|c|c|c|c|c|}
\hline \multirow[b]{2}{*}{ No } & \multirow[b]{2}{*}{ Bidang/Sektor } & \multicolumn{2}{|c|}{ Jumlah saham } & \multirow[b]{2}{*}{ Nama saham yang masuk } & \multirow[b]{2}{*}{ Total bobot aset } \\
\hline & & $\begin{array}{l}\text { Tersedia pada } \\
\text { indeks LQ-45 }\end{array}$ & $\begin{array}{c}\text { Masuk dalam } \\
\text { portofolio optimum }\end{array}$ & & \\
\hline & Perkebunan & 3 & 2 & AALI, SSMS & $23,8 \%$ \\
\hline 2 & Pertambangan & 6 & 3 & ADRO, ANTM, PTBA & $3,3 \%$ \\
\hline & Perbankan & 5 & 4 & BBCA, BBNI, BBTN, BMRI & $34,7 \%$ \\
\hline 4 & Barang konsumsi & 6 & 3 & HMSP, KLBF, UNVR & $15,3 \%$ \\
\hline 5 & Properti dan Real Estate & 11 & 4 & LPKR, MYRX, PPRO, PTPP & $11,5 \%$ \\
\hline 6 & Infrastruktur dan komunikasi & 4 & 2 & JSMR, TLKM & $2,7 \%$ \\
\hline 7 & Perdagangan dan Jasa & 5 & 2 & $\mathrm{LPPF}, \mathrm{MNCN}$ & $1,1 \%$ \\
\hline 8 & Industri dasar dan kimia & 3 & 1 & SMGR & $5,9 \%$ \\
\hline 9 & Industri lain-lain & 1 & 1 & SRIL & $1,2 \%$ \\
\hline
\end{tabular}


sebesar 34,7\%) dan dari saham-saham yang dimiliki oleh perusahaan swasta (bobot sebesar 75,6 \%). Oleh karena itu, dalam penelitian ini diberikan batas maksimum jumlah saham dari sektor perbankan dan dari perusahaan swasta yang dapat dimasukkan ke dalam portofolio optimum. Guna membandingkan kinerja portofolio dengan tambahan kendala terkait karakteristik perusahaan emiten terhadap kinerja portofolio tanpa tambahan kendala (model mean-variance klasik menurut Markowitz[4]) yang telah dibahas di muka, dibentuk empat macam portofolio dengan spesifikasi sebagai berikut.

P2: portofolio variansi minimum dengan komposisi maksimum dua saham dari sektor perbankan

P3: portofolio variansi minimum dengan komposisi maksimum dua saham dari sektor perbankan dan maksimum dua saham dari sektor properti dan real estate

P4: portofolio variansi minimum dengan komposisi maksimum sepuluh saham perusahaan swasta

P5: portofolio variansi minimum dengan komposisi maksimum sepuluh saham perusahaan swasta dan maksimum dua saham dari sektor properti dan real estate

Batasan terkait jumlah saham sektor properti dan real estate pada portofolio P3 dan P5 berturut-turut digunakan sebagai pembanding terhadap portofolio P2 dan P4, yakni bila terdapat lebih dari satu batasan. Pemilihan ini didasarkan pada adanya empat saham LQ-45 pada sektor properti dan real estate yang dapat membentuk portofolio optimum seperti ditunjukkan pada Tabel 3, sehingga diharapkan terdapat perbedaan hasil pada portofolio tanpa pembatasan.

Untuk menentukan saham-saham yang menyusun portofolio P2 hingga P5, digunakan algoritma genetika dengan langkah-langkah sesuai penjelasan di muka. Operator penyilangan yang digunakan adalah penyilangan seragam (uniform crossover) dengan probabilitas sebesar 0,7; sedangkan operator mutasi yang digunakan adalah mutasi acak (random mutation) dengan probabilitas sebesar 0,05 (mengacu pada Mansini et al. [18] dan Chang et al. [23]). Seleksi kromosom dilakukan menggunakan metode yang paling sederhana yakni roulette wheel. Pada metode ini, seleksi dilakukan dengan mengelompokkan kromosom ke dalam beberapa kelompok dan mempertahankan kromosom dengan nilai fitness tertinggi pada masing-masing kelompok (Zuhri [20]). Ukuran populasi yang dipilih adalah sebesar 50, yakni ukuran populasi terkecil yang memiliki keunggulan pada proses inisialisasi (Chang et al.[23]). Besarnya elitisme ditetapkan sebesar 3 , yang berarti bahwa tiga kromosom dengan fitness tertinggi pada setiap generasi tidak ikut mengalami crossing over maupun mutasi.
Dalam penelitian ini, algoritma genetika dikerjakan dengan bantuan pustaka GA versi 3.0.2 yang terdapat pada perangkat lunak $\mathrm{R}$, sedangkan pembentukan portofolio optimum mean-variance dikerjakan dengan bantuan pustaka fPortfolio versi 3011.81. Analisis dikerjakan pada komputer dengan prosesor Intel i5 dan RAM sebesar 4 GB. Hasil perhitungan algoritma genetika pada pembentukan keempat portofolio tersebut adalah sebagai berikut.

Gambar 2 menunjukkan besarnya nilai rata-rata dan nilai maksimum fitness pada populasi yang terbentuk oleh algoritma genetika dari generasi awal (ke-1) hingga generasi ke-200. Telah disebutkan di muka bahwa fungsi fitness didefinisikan sebagai negatif dari variansi portofolio, sedangkan penaltinya dibuat dengan mengurangkan 100 pada fungsi fitness bila kendala tidak terpenuhi. Pada Gambar 2, nampak jelas bahwa pada sekitar generasi ke-100 telah diperoleh solusi terbaik yang cenderung stabil. Dengan membandingkan pergerakan nilai rata-rata pada fungsi fitness pada portofolio P2 dengan ketiga portofolio lainnya, terlihat pula bahwa solusi pada pengoptimuman portofolio dengan kendala yang lebih sederhana dapat diperoleh pada generasi lebih awal.

Bobot aset pada portofolio optimum P2, P3, P4, dan P5 hasil pemilihan saham dengan algoritma genetika da-pat dilihat pada Tabel 4. Hasil tersebut akan dibandingkan dengan portofolio P1, yakni portofolio mean-variance Markowitz berdasarkan seluruh saham penyusun indeks LQ-45 (Gambar 1).

Dari Tabel 4, terlihat bahwa seluruh portofolio yang dibentuk menggunakan algoritma genetika telah memenuhi kendala yang dipersyaratkan. Sebagai contoh, portofolio P2 dan P3 hanya memuat satu saham perbankan, yakni BBCA, yang merupakan saham perbankan dengan risiko terkecil (lihat Tabel 1). Contoh lain, portofolio P3 dan P5 hanya memuat dua saham sektor properti dan real estate dengan risiko terkecil, sedangkan portofolio $\mathrm{P} 4$ dan $\mathrm{P} 5$ hanya memuat 9 saham perusahaan swasta. Lebih lanjut, portofolio P2, P3, P4, dan P5 berturut-turut memuat sebanyak $21,18,17$, dan 17 saham, lebih kecil dari portofolio P1 yang memuat 24 saham.

Hal-hal tersebut menunjukkan bahwa algoritma genetika dapat bekerja dengan efektif dalam menyelesaikan masalah pembentukan portofolio optimum dengan kendala terkait kondisi perusahaan emiten.

Algoritma genetika dapat membantu investor terutama para investor jangka panjang dalam menerapkan kriteria-kriteria pemilihan saham yang akan dimasukkan ke dalam portofolio investasinya. Seperti diketahui, pada umumnya investor jangka 

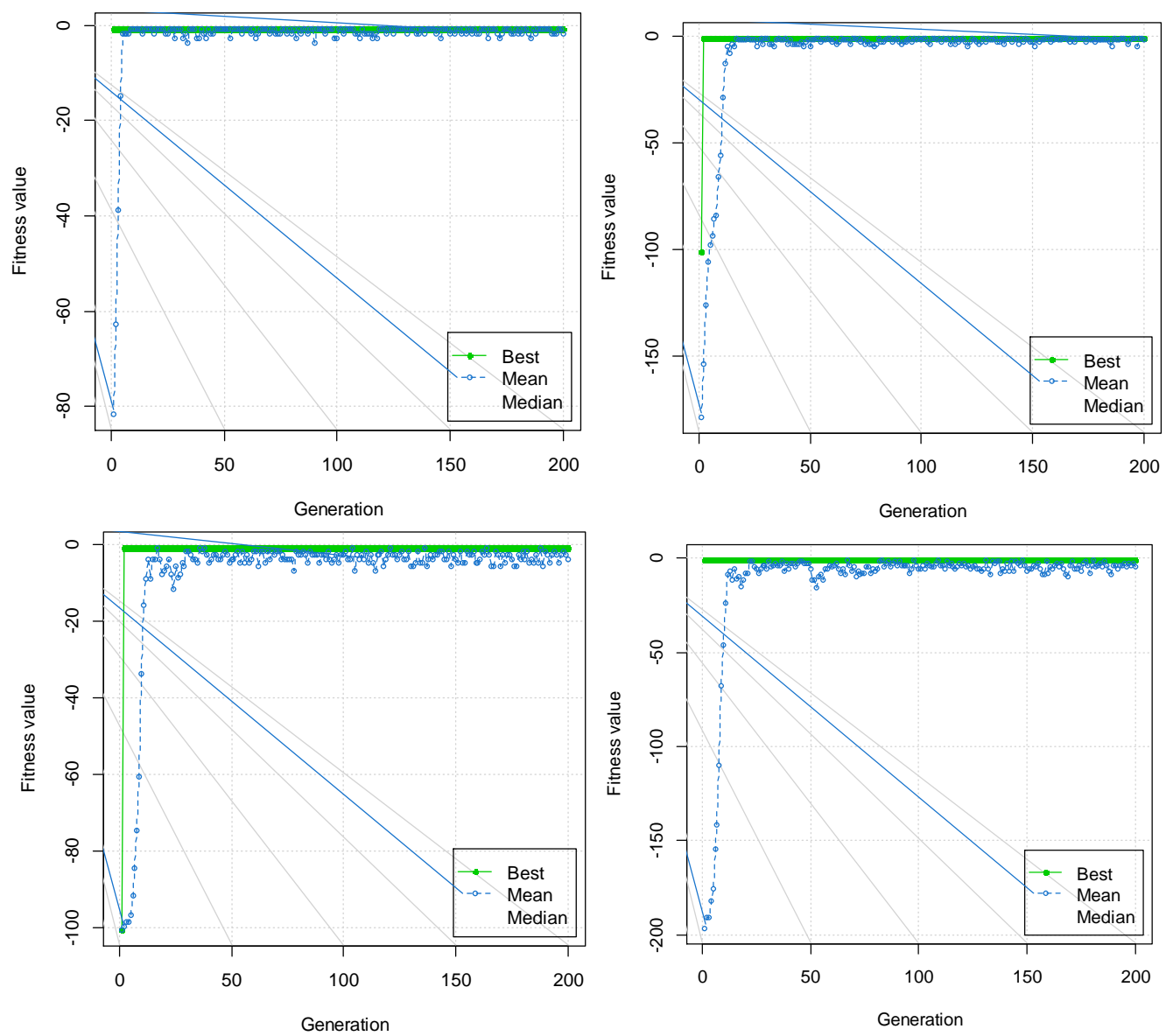

Gambar 2. Hasil algoritma genetika pada pembentukan portofolio P2, P3, P4, dan P5 (dari atas ke bawah)

Tabel 4. Komposisi portofolio optimum P1, P2, P3, P4, dan P5

\begin{tabular}{|c|c|c|c|c|c|c|c|}
\hline \multirow{2}{*}{ Nomor } & \multirow{2}{*}{ Kode saham* } & \multirow{2}{*}{ Sektor industri } & \multicolumn{5}{|c|}{ Bobot aset pada portofolio optimum } \\
\hline & & & $\mathrm{P} 1$ & P2 & P3 & $\mathrm{P} 4$ & P5 \\
\hline 1 & AALI & Perkebunan & $12,5 \%$ & $12,6 \%$ & $13,5 \%$ & $13,8 \%$ & $13,3 \%$ \\
\hline 2 & $\mathrm{ADRO}$ & Pertambangan & $1,7 \%$ & $2 \%$ & $1,6 \%$ & - & - \\
\hline 3 & ANTM & Pertambangan & $0,7 \%$ & $1,2 \%$ & $1,9 \%$ & $0,5 \%$ & $0,8 \%$ \\
\hline 4 & BBCA & Bank & $21,5 \%$ & $24 \%$ & $23,9 \%$ & $22,7 \%$ & $22,4 \%$ \\
\hline 5 & $B B N I$ & Bank & $8,8 \%$ & - & - & $8,9 \%$ & $9,1 \%$ \\
\hline 6 & $B B T N$ & Bank & $3,5 \%$ & - & - & $4,1 \%$ & $4,2 \%$ \\
\hline 7 & $B M R I$ & Bank & $0,9 \%$ & - & - & $2,1 \%$ & $2 \%$ \\
\hline 8 & EXCL & Infrastruktur dan komunikasi & - & $0,1 \%$ & - & - & - \\
\hline 9 & GGRM & Barang konsumsi & - & $0,4 \%$ & $0,6 \%$ & - & - \\
\hline 10 & HMSP & Barang konsumsi & $2,9 \%$ & $3,1 \%$ & $2,9 \%$ & $3 \%$ & $3,1 \%$ \\
\hline 11 & $J S M R$ & Infrastruktur dan komunikasi & $2,2 \%$ & $3,6 \%$ & $3,7 \%$ & $3,1 \%$ & $2,3 \%$ \\
\hline 12 & KLBF & Barang konsumsi & $1,7 \%$ & $3 \%$ & $3,1 \%$ & - & - \\
\hline 13 & LPKR & Properti dan real estate & $4,9 \%$ & $5,5 \%$ & $5,4 \%$ & - & - \\
\hline 14 & $\mathrm{LPPF}$ & Perdagangan dan jasa & $1,1 \%$ & $0,9 \%$ & $0,8 \%$ & - & $1,7 \%$ \\
\hline 15 & MNCN & Perdagangan dan jasa & $0,6 \%$ & $0,9 \%$ & $1 \%$ & - & - \\
\hline 16 & MYRX & Properti dan real estate & $3,1 \%$ & $2,9 \%$ & - & $3 \%$ & $3 \%$ \\
\hline 17 & PPRO & Properti dan real estate & $1,4 \%$ & $1,6 \%$ & - & $1,4 \%$ & - \\
\hline 18 & $P T B A$ & Pertambangan & $0,9 \%$ & $0,9 \%$ & $1,2 \%$ & $1,4 \%$ & $1,8 \%$ \\
\hline 19 & $P T P P$ & Properti dan real estate & $2,1 \%$ & $2,6 \%$ & $3,4 \%$ & $2,5 \%$ & $3,1 \%$ \\
\hline 20 & $S M G R$ & Industri dasar dan kimia & $5,9 \%$ & $7,4 \%$ & $7,4 \%$ & $7,5 \%$ & $7,6 \%$ \\
\hline 21 & SRIL & Industri lain-lain & $1,2 \%$ & $1 \%$ & $0,9 \%$ & $1,3 \%$ & $1,2 \%$ \\
\hline 22 & SSMS & Perkebunan & $11,3 \%$ & $10,5 \%$ & $10,8 \%$ & $10,6 \%$ & $10,6 \%$ \\
\hline 23 & $T L K M$ & Infrastruktur dan komunikasi & $0,5 \%$ & $2,9 \%$ & $4,1 \%$ & $1,8 \%$ & $1,9 \%$ \\
\hline 24 & UNVR & Barang konsumsi & $10,7 \%$ & $12,8 \%$ & $13,7 \%$ & $12,2 \%$ & $12,1 \%$ \\
\hline
\end{tabular}

* Kode saham yang dicetak miring merupakan saham perusahaan BUMN 


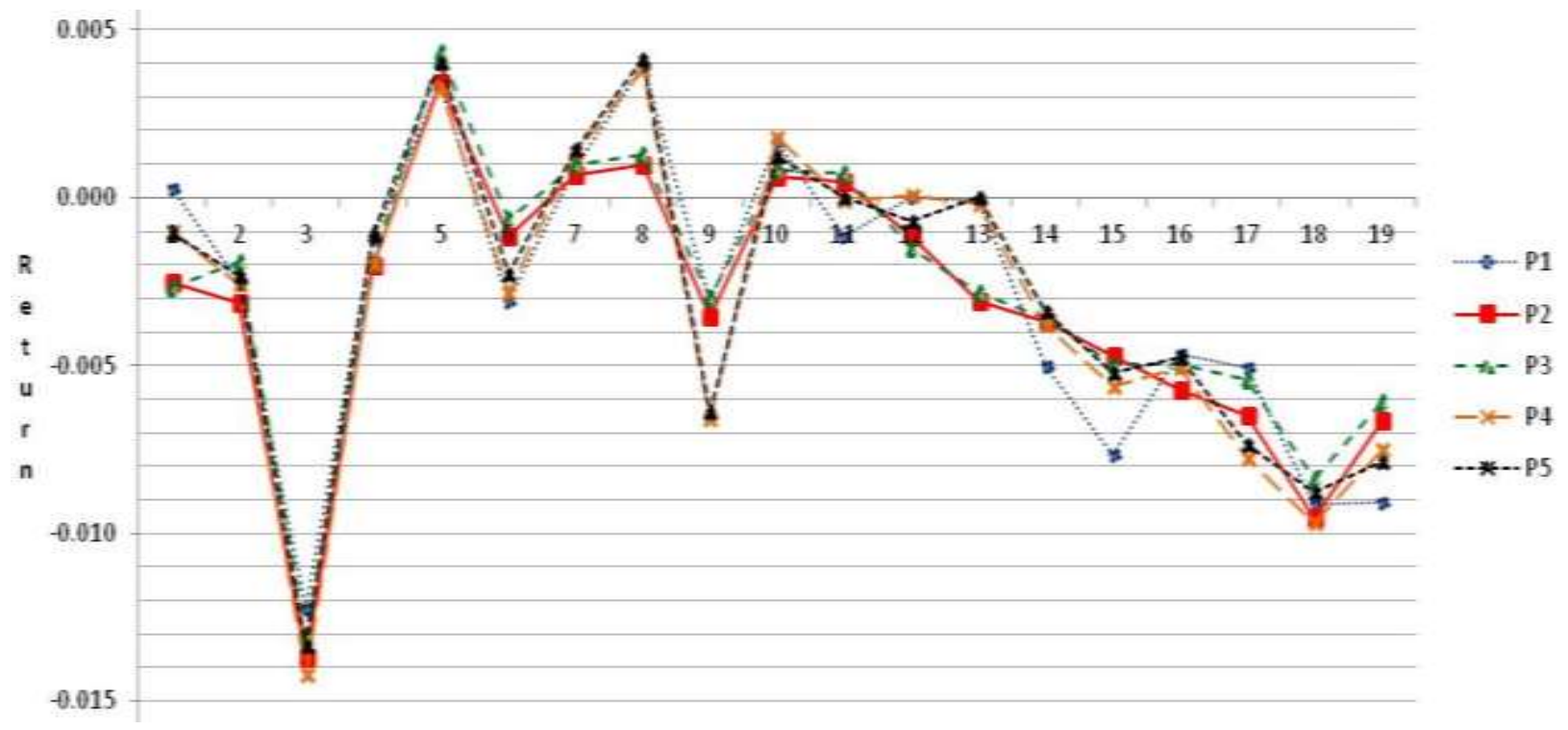

Gambar 3. Kinerja portofolio P1, P2, P3, P4, dan P5 pada data out sample

panjang menggunakan analisis fundamental dalam penentuan portofolionya, yang melibatkan berbagai variabel selain pergerakan return saham (Samsul [1]). Tentu saja investor juga harus menentukan jumlah saham yang dikehendaki pada masingmasing sektor.

Selanjutnya akan dibandingkan pula kinerja kelima portofolio, yakni portofolio dengan variansi minimum menurut Markowitz (P1) serta keempat portofolio dengan tambahan kendala terkait kriteria perusahaan emiten (P2, P3, P4, dan P5). Perbandingan dilakukan dengan mengamati kinerja out sample, yakni perge-rakan tingkat pengem-balian (return) portofolio setelah pembentukan saham yakni pada bulan September 2017. Grafik kinerja portofolio-portofolio tersebut dapat dilihat pada Gambar 3.

Dari Gambar 3, terlihat bahwa penggunaan kriteria yang tepat dapat memperbaiki kinerja portofolio model Markowitz (P1) yang ditunjukkan oleh garis hitam. Sebagai contoh pada ujung kanan grafik terlihat bahwa portofolio P2-P4 memiliki return lebih tinggi dibandingkan P1. Kondisi sebaliknya terjadi di bagian kiri grafik, kerugian yang dialami P1 kadangkala tidak sebesar portofolio-portofolio lain. Hal ini disebabkan oleh jumlah saham yang lebih besar, sehingga kerugian pada salah satu saham dapat "ditutup" oleh keuntungan pada saham lainnya.

Secara lebih detail, Tabel 5 menunjukkan bahwa pemilihan kriteria yang tepat dapat menghasilkan portofolio dengan kerugian yang lebih kecil dan/atau simpangan baku yang lebih kecil dibandingkan portofolio variansi minimum model Markowitz.
Tabel 5. Kinerja portofolio P1, P2, P3, P4, dan P5

\begin{tabular}{ccc}
\hline Portofolio & Jumlah return & Simpangan baku return \\
\hline P1 & $-5,37 \%$ & $0,44 \%$ \\
P2 & $-6,08 \%$ & $0,40 \%$ \\
P3 & $-5,28 \%$ & $0,39 \%$ \\
P4 & $-5,85 \%$ & $0,47 \%$ \\
P5 & $-5,36 \%$ & $0,45 \%$ \\
\hline
\end{tabular}

Bagi investor penghindar risiko (risk averse), portofolio P3 memiliki keunggulan dibandingkan P1, yakni kerugian yang lebih kecil dan simpangan baku yang lebih kecil. Adapun bagi investor penyuka risiko, portofolio $\mathrm{P} 2$ dan $\mathrm{P} 4$ mungkin dirasa lebih menarik karena adanya potensi untuk memperoleh keuntungan lebih besar dibandingkan portofolio P1. Portofolio P5 juga memiliki keunggulan, yakni disusun oleh 17 macam saham namun memiliki kinerja yang hampir sama dengan portofolio P1 yang disusun oleh 21 macam saham.

Riset-riset lebih lanjut diperlukan untuk menentukan kriteria-kriteria fundamental yang dapat digunakan untuk membedakan perusahaan-perusahaan emiten saham, misalnya ada tidaknya pembagian dividen, kategori besarnya modal atau keuntungan, dan lain sebagainya. Penggunaan kriteria yang sesuai, diharapkan dapat diperoleh portofolio investasi yang lebih baik.

\section{Simpulan}

Masalah pengoptimuman portofolio variansi minimum dengan penambahan kendala terkait karakteristik perusahaan emiten dapat diselesaikan dengan metode algoritma genetika (genetic algorithm). Studi kasus menunjukkan bahwa dengan memilih kriteria yang tepat, portofolio yang dihasilkan dengan penambahan kendala tertentu terkait perusahaan 
emiten akan memiliki kinerja yang lebih baik dibandingkan portofolio variansi minimum tanpa penambahan kendala. Diperlukan penelitian lebih lanjut diperlukan untuk mengungkap berbagai kriteria terkait perusahaan emiten yang digunakan sebagai kendala dalam model ini guna meningkatkan kinerja portofolio yang terbentuk, maupun menentukan jumlah maksimum saham yang optimum dari masing-masing kategori atau masingmasing sektor.

\section{Daftar Pustaka}

1. Samsul, M., Pasar Modal dan Manajemen Portofolio, Edisi kedua, Erlangga, Jakarta, 2015.

2. Goetzmann, W.N., Kumar, A., Equity Portfolio Diversification, Review of Finance, 12, 2008, pp. 433-463.

3. Elton, E. J., Gruber, M. J., Brown, S. J., Goetzmann, W. N., Modern Portfolio Theory and Investment Analysis, Ninth edition, John Wiley and Sons, New York, 2014.

4. Markowitz, H.M., Portfolio Selection, Journal of Finance, 7, 1952, pp. 77-91.

5. Supandi, E. D., Rosadi, D., Abdurakhman, An Empirical Comparison between Robust Estimation and Robust Optimization to Mean-Variance Portfolio, Journal of Modern Applied Statistical Methods, 16(1), 2017, pp. 589-611.

6. Soleimani, H., Golmakani, H.R., Salimi, M.H., Markowitz-based Portfolio Selection with Minimum Transaction Lots, Cardinality Constraint, and Regarding Sector Capitalization using Genetic Algorithm, Expert Systems with Applications, 36, 2009, pp. 5058-5063.

7. Lhwin, K., Qu, R., A Hybrid Algorithm for Constrained Portfolio Selection Problems, Applied Intelligence, 39, 2013, pp. 251-266.

8. Adam, P., Rianse, U., Cahyono, E., Rahim, M., Modeling of the Dynamics Relationship between World Crude Oil Prices and the Stock Market in Indonesia, International Journal of Energy Economics and Policy, 5(2), 2015, pp. 550-557.

9. Mutumanikam, P.R., Analisis Pengaruh Faktor Makroekonomi terhadap Return Saham di Bursa Efek Indonesia, Tesis, Magister Manajemen, Universitas Gadjah Mada, Yogyakarta, 2014.

10. Hartanto, I.B., Analisis Kausal Antara Nilai Tukar dan Return Saham Sektoral pada Bursa Efek Jakarta, Tesis, Magister Manajemen, Universitas Gadjah Mada, Yogyakarta, 2006.
11. Hartanto, T., Analisis Kepekaan Indeks Harga Saham Sektoral terhadap Perubahan Nilai Tukar Rupiah dengan US dollar di Bursa Efek Jakarta, Tesis, Magister Manajemen, Universitas Gadjah Mada, 1999.

12. Rahmi, J. S., Kinerja Portofolio Saham Sektor Perdagangan, Sektor Infrastruktur, dan Sektor Pertambangan, Skripsi, Departemen Manajemen, Institut Pertanian Bogor, Bogor, 2017.

13. Isdiansyah, M.W., Analisis Perbandingan Risk dan Return antara Saham BUMN dengan Saham Swasta: Studi pada Saham LQ 45 Sektor Perbankan 2011-2014, Skripsi, Jurusan Manajemen, Universitas Islam Negeri Maulana Malik Ibrahim, Malang, 2015.

14. Bienstock, D., Computational Study of a Family of Mixed-Integer Quadratic Programming Problems, Mathematical Programming, 74, 1996, pp. 121-140.

15. Chang, T.J., Yang, S-C., Chang, K-J., Portfolio Optimization Problems in Different Risk Measures using Genetic Algorithm, Expert System with Applications, 36, 2009, pp. 10529-15037.

16. Woodside-Oriakhi, M., Lucas, C., Beasley, J.E., Heuristic Algorithms for the Cardinality Constrained Efficient Frontier, European Journal of Operational Research, 213, 2011, pp. 538-550.

17. Angelelli, E., Mansini, R., Speranza, M.G., A Comparison of MAD and CVaR Models with Real Features, Journal of Banking and Finance, 32, 2008, pp. 1188-1197.

18. Mansini, R., Ogryczak, W., Speranza, M.G., Linear and Mixed Integer Programming for Portfolio Optimization, Springer International Publishing, Switzerland, 2015.

19. Lin, C-C., Liu, Y-T., Genetic Algorithms for Portfolio Selection Problems with Minimum Transaction Lots, European Journal of Operational Research, 185, 2008, pp. 393-404.

20. Zuhri, Z., Algoritma Genetika: Metode Komputasi Evolusioner untuk Menyelesaikan Masalah Optimasi, Penerbit Andi, Yogyakarta, 2014.

21. Haupt, R.L, Haupt, S.E., Practical Genetic Algorithm, Second edition, John Wiley and Sons, New Jersey, 2004.

22. Arnone, S., Loraschi, A., Tettamanzi, A., A Genetic Approach to the Portfolio Selection, Neural Network World, 6, 1993, pp. 597-604.

23. Chang, T.J., Meade, N., Beasley, J.E., Sharaiha, Y.M., Heuristic for Cardinality Constrained Portfolio Optimization, Computer and Operational Research, 27, 2000, pp. 1271-1302. 